\title{
Some Quality Parameters of Powdered Soups Prepared from Different Fish Species
}

Fatma Öztürk ${ }^{1}$

https://orcid.org/0000-0003-4763-3801

Selin Kalkan ${ }^{*}$

https://orcid.org/0000-0002-4142-3152

Ercan Elmas ${ }^{1}$

https://orcid.org/0000-0002-1109-7093

\section{Sercan Elmas ${ }^{1}$}

https://orcid.org/0000-0002-8772-5367

\section{Pelin Bariş ${ }^{1}$}

https://orcid.org/0000-0002-2422-5680

\section{Özlem Demir ${ }^{1}$}

https://orcid.org/0000-0002-4987-9584

${ }^{1}$ İzmir Katip Çelebi University, Faculty of Fisheries, Izmir, Turkey; ${ }^{2}$ Giresun University, Faculty of Engineering, Department of Food Engineering, Giresun, Turkey.

Received: 2018.07.17; Accepted: 2019.07.08.

* $\quad$ Correspondence: selin.kalkan@giresun.edu.tr; Tel.: +90 4543104117 (F.L.)

\section{HIGHLIGHTS}

- Powdered soups were prepared from different fish species.

- Soups were evaluated in terms of chemical, microbiological and sensory parameters.

- Prepared powdered fish soups were rich in protein, fat, and minerals.

- Preferred products was obtained with microbiological and sensory properties.

Abstract: In this study, we aim to determine the shelf life of dried and ready to usepowdered soup samples obtained from different types of fish species such as Rainbow trout (Oncorhynchus mykiss), sea bream (Sparusaurata L.) and sea bass (Dicentrarchuc labrax). For this purpose, the chemical (moisture, protein, fat, carbohydrate, ash, $\mathrm{pH}$, Thiobarbituric acid (TBA), Total volatile basic nitrogen (TVB-N), microbiological (total mesophilic aerobic bacteria, total yeast and mold, total coliform, Staphylococcus spp. and 
Salmonella spp.) and sensory properties of fish soup samples were determined during 6month storage period. The $\mathrm{pH}, \mathrm{TBA}$ and TVB-N values of all samples increased during the storage period, but these values were within the consumption limits. Additionally, the microbiological properties of all fish soup samples were found within the consumption limits during storage. As a result, a product has been obtained with high nutritional value and rich with regard to protein, oil, and minerals by adding the fish meat to soup samples. It has been determined that the product quality and shelf life significantly increased by using the boiled product for the production of soup samples.

Keywords: Fish soups, Thiobarbituric acid (TBA), Total volatile basic nitrogen (TVB-N), Storage, Quality

\section{INTRODUCTION}

The increase in the world population leads to narrowing of the land-based food sources and it makes compulsory to the alternative food production. Hunger or inadequate nutrition brought about by the increasing population growth in recent years, it increases the need for animal protein. Therefore, the necessary work to achieve a maximum product of the available natural resources in our country as well as in other countries, obtained by the product good evaluation as possible, preservation and presentation for human consumption are important $[1,2,3]$.

People live a busy life due to urbanization. They do not have enough time to cook food and they have started to eat fast food. Most of these fast foods have high sugar, fat and salt content, and contain low amounts of protein, fiber, vitamins, and minerals. Consumption of these foods causes malnutrition and nutrition-related diseases [4, 5]. Diet and nutrition are crucial to promoting and maintaining health throughout life. It is recommended that the soup, which stimulates salivary secretion and gastric peristalsis of the stomach, should be included in the human diet to help reduce energy intake and promote weight loss [6, 7]. It has been demonstrated that soup leads to slow and moderate insulin secretion, which is prone to increase meal saturation [8].

Soup is a heterogeneous food prepared using Vegetable, fish, meat, water, juice, broth and some stabilization substances. Instant soup is one of the foods highly preferred by modern society due to its simple, easy preparation properties [3, 9, 10]. Soup powders prepared using different raw materials such as vegetables, meat, cereals and chicken are very popular worldwide [3, 11-14]. Furthermore, powdered soups prepared by using fish, shrimp, and oysters and formulated with standard recipes have become an accepted foodstuff and have achieved commercial success [11]. Fish is the cheapest source of much needed animal protein. On an average, the protein content of fish range from $18-22 \%$ [15]. Therefore, it is important that the total available catch may be put to maximum use as food for human consumption. It is possible if surplus catches of certain cheap varieties of fish could be utilized for the manufacture of protein rich product such as fish soup powder, fish protein concentrate, etc. $[8,16]$.

The amount of animal protein per capita in Turkey is known to be significantly lower than the EU countries and the United States. Seafood products that are superior in terms of features such as the amount of protein, energy, minerals, vitamins and digestibility, to overcome the shortage of protein of our people as well as this is a source that may contribute to changes in the positive direction of both diets. The average annual of fish consumption is $19.2 \mathrm{~kg}$ per capita in the world, $22 \mathrm{~kg}$ in the European Union and $8 \mathrm{~kg}$ in Turkey [17]. Increasing the amount is great importance. While some countries which are aware of a balanced diet looking for ways to benefit from the high seas and inland waters to further enhance animal protein sources, fish consumption in Turkey is not at the desired level when compared with the US and EU countries.

While a large part of seafood product is consumed as fresh and chilled, demand for ready food has increased significantly in recent years. Comprehensive studies being conducted in the form of processed products such as burger, croquettes and meatballs for benefiting from seafood products. At this point, ready soups, concentrates and powder 
mixture tasty, practically ready and with high-quality varieties are becoming an important option with new formulations. Instant soups dried foods offered to the consumer, which are prepared with a mixture of several substances such as dehydrated foods, various mixtures thereof, and starch $[18,19]$. Health and nutritional value, high cuisine can be transported to the kitchens with quick soups and soup powder at the market. Although Turkey is a rich country in terms of potential of aquatic products, the annual per capita fish consumption is observed to be very low compared to the EU countries and the world average. Fish soup is a product that could support our country overcomes the lack of fish consumption. As a subject of research and promotion of fish soup is considerable importance with rich nutrient content and in terms of care contributes to the economy. In this study, we aim to obtain powder mixtures using different types of fish soup and determine the shelf life of fish soup mixtures with investigating some of chemical, microbiological and sensory quality parameters.

\section{MATERIAL AND METHODS}

\section{Preparation of powdered soup mixtures}

Rainbow trout (Oncorhynchus mykiss), sea bream (Sparusaurata L.) and sea bass (Dicentrarchus labrax) fish species were obtained from commercial production facility and İzmir, Turkey fish market. All vegetables and spices used in this study were obtained from the local supermarkets in İmir. Formulation of fish soup samples was given in Table 1.

Table 1. Ingredients used for preparation of powdered soups samples

\begin{tabular}{lc}
\hline Ingredients & Quantity added $(\mathbf{g})$ \\
\hline Dried fish meat & 35 \\
Wheat flour & 20 \\
Cornstarch & 10 \\
Carrot & 4 \\
Potatoes & 4 \\
Onion & 3 \\
Garlic & 3 \\
Salt & 2,5 \\
Lemon salt & 2,5 \\
Black pepper & 1 \\
Parsley & 0,5 \\
Powdered red pepper & 0,1 \\
\hline
\end{tabular}

In this study, fish soup mixtures were prepared by boiling process. The fish fillets were sliced to $1-1.5 \mathrm{~cm}$ for soup powder production. Vegetables were sliced to $0.5 \mathrm{~cm}$ in size and cooked using a small amount of water mixed with fish meat. Then this mix was dried at 50 ${ }^{\circ} \mathrm{C}$ during the moisture level down to the level of $10 \%$ by using drying oven. These dried products were mixed with other ingredients specified in the formulation and packaged. Soups were prepared in 100-gram packages and kept in dry and cool conditions in a sunless cabinet. Vacuum packaging metallized lamination was used as soups packaging. Packaging materials were three-layered. Polietilentetraftalat (PET) formed it at outer layer, oriental polypropylene (OPP) at middle layer and polyethylene (PE) at the inner layer. All soup samples, vacuum packed were stored for 6 months at room temperature.

\section{Chemical analyses}

The chemical composition of fish soup samples such as protein, fat, moisture, carbohydrate and ash was determined according to The Association of Official Analytical Chemists [20]. 
The chemical changes were investigated that may occur during storage of the all soup samples. For this purpose, the $\mathrm{pH}$, Thiobarbituric Acid Analysis (TBA) and Total Volatile Basic Nitrogen (TVB-N) analysis were performed at $1^{\text {st }}, 2^{\text {nd }}, 3^{\text {rd }}, 4^{\text {th }}, 5^{\text {th }}$ and $6^{\text {th }}$ months of storage period. A $10 \mathrm{~g}$ sample of the soups was homogenized in $100 \mathrm{~mL}$ of distilled water and the mixture was filtered. The $\mathrm{pH}$ of filtrate was measured using a digital $\mathrm{pH}$ meter (Ohaus Starter 3000 Parsippany, NJ 07054, USA) [7]. The TBA analyses were performed as described by Tarladgis et al. [21]. The TVB-N analysis were carried out according to the method described by Goulas and Kontominas [22].

\section{Microbiological analyses}

Microbiological changes that may occur of all soup samples during storage period were examined. For these analyses, $10 \mathrm{~g}$ soup samples were homogenized with $90 \mathrm{~mL}$ Maximum Recovery Diluent (MRD, Merck). The analyses were carried out in 2 parallel and 3 replicates in accordance with the FDA Bacteriological Analytical Manual [23]. Petri dishes were incubated for the mesophilic aerobic bacteria count at $30^{\circ} \mathrm{C}$ for 48 hours by using Plate Count Agar (PCA, Merck), for yeast and mold count at $30^{\circ} \mathrm{C}$ for 72 hours by using Potato Dextrose Agar (PDA, Merck), for coliform bacteria at $37^{\circ} \mathrm{C}$ for 24 hours by using Fluoracult Violet Red Bile Agar (FVRB, Merck) and for Staphylococcus spp. at $37^{\circ} \mathrm{C}$ for 24 hours by using Baird Parker Agar (BPA, Merck). For Salmonella spp. analysis, $25 \mathrm{~g}$ of soup sample was homogenized by transferring $225 \mathrm{~mL}$ of sterile buffered peptone water (TPS) and this homogenized was incubated at $37^{\circ} \mathrm{C}$ for $16-20$ hours. After incubation, $0.1 \mathrm{~mL}$ of advanced culture in TPS medium was transferred to $10 \mathrm{ml}$ Rapoport-Vassiliadis Broth (RV) and this culture was incubated at $43^{\circ} \mathrm{C}$ for 24 hours. At the end of this incubation time RV cultures were transferred to Rambach Agar and were incubated at $37^{\circ} \mathrm{C}$ for $24-48$ hours. Red colonies were evaluated as Salmonella spp. at the end of incubation. Bacterial counts were expressed as log10 colony forming units (CFU)/g sample.

\section{Sensory analyses}

The fish soup samples stored were analyzed by ten different expert panelists (performed as two replications and 5 panelists were used in each repetition) using a sensory rating scale rating some sensory parameters (color, odor, appearance, flavor, chewing feature and overall acceptability) from 1 (poor) to 5 (excellent).

\section{Statistical analyses}

The obtained data from all the analyses were exposed to the analysis of variance in the study by using IBM SPSS Statistic 19.0 software (IBM Corporation, Somers, NY, USA). Duncan's multiple range tests at $(p \leq 0.05)$ level were used to compare between means [24].

\section{RESULTS}

\section{Chemical composition of soup samples}

The chemical composition results of the powdered soup samples were given in Table 2. As seen in Table 2, rainbow trout (Oncorhynchus mykiss; TS) soup samples have the highest protein content with $37.017 \pm 5.862 \%$ value and sea bass (Dicentrarchuclabrax; SBS) fish soup samples have the lowest protein content with $28.097 \pm 1.312 \%(p \leq 0.05)$. While the fattiest fish soup was TS soup samples, sea bream (Sprausaurata L.; SBRS) with a minimum fat content of $5.61 \pm 0.24 \%(p \leq 0.05)$. These results were expected because the rainbow trout contain a higher fat content than the sea bass and sea bream When the values given in Table 2 are evaluated in terms of moisture content, soup samples with the highest moisture content were determined as SBRS with $10.61 \pm 0.84 \%$. TS soup samples have the lowest moisture content with $8.69 \pm 0.53 \%$ ( $p \leq 0.05)$. When soup samples were evaluated in terms of ash content, SBRS soup samples had the highest ash content of $7.10 \pm 0.73 \%$, while the lowest ash content was detected in TS soup samples with $6.19 \pm 0.06 \%(p \leq 0.05)$. The highest carbohydrate content was SBS soup samples with the highest value of $50.85 \pm 2.46 \%$, while 
the lowest carbohydrate content was determined in TS soup samples with $40.14 \pm 5.58 \%$ $(p \leq 0.05)$.

Table 2. The chemical composition of powdered fish soup samples (\%)

\begin{tabular}{lccccc} 
Groups* & Protein & Fat & Moisture & Ash & Carbohydrates \\
\hline TS & $37.10^{\mathrm{c}} \pm 5.862$ & $7.87^{\mathrm{b}} \pm 0.187$ & $8.69^{\mathrm{a}} \pm 0.530$ & $6.19^{\mathrm{a}} \pm 0.061$ & $40.14^{\mathrm{a}} \pm 5.580$ \\
& & & & & \\
SBS & $28.09^{\mathrm{a}} \pm 1.312$ & $5.80^{\mathrm{a}} \pm 0.108$ & $9.00^{\mathrm{a}} \pm 1.571$ & $6.25^{\mathrm{a}} \pm 2.318$ & $50.85^{\mathrm{c}} \pm 2.469$ \\
& & & & & \\
SBRS & $30.40^{\mathrm{b}} \pm 0.481$ & $5.61^{\mathrm{a}} \pm 0.244$ & $10.61^{\mathrm{b}} \pm 0.843$ & $7.10^{\mathrm{b}} \pm 0.738$ & $46.27^{\mathrm{b}} \pm 1.818$
\end{tabular}

${ }^{*}$ TS: Rainbow trout soup; SBS: Sea bass soup; SBRS: Sea bream soup **Data expressed as mean \pm SD. a-c: Values in the same column sharing the same superscript letter are not significantly different $(p>0.05)$.

\section{Analyses of storage periods}

The $\mathrm{pH}$ values of soups samples were shown in Figure 1. It was statistically significant relationship between the storage time and the $\mathrm{pH}$ values $(\mathrm{p} \leq 0,05)$. As shown in Figure 1 , the $\mathrm{pH}$ values of the samples were varied between 4.98 and 5.82. TS soup samples were found to have the highest $\mathrm{pH}$ value and $\mathrm{SB}$ soup samples had the lowest $\mathrm{pH}$ value.

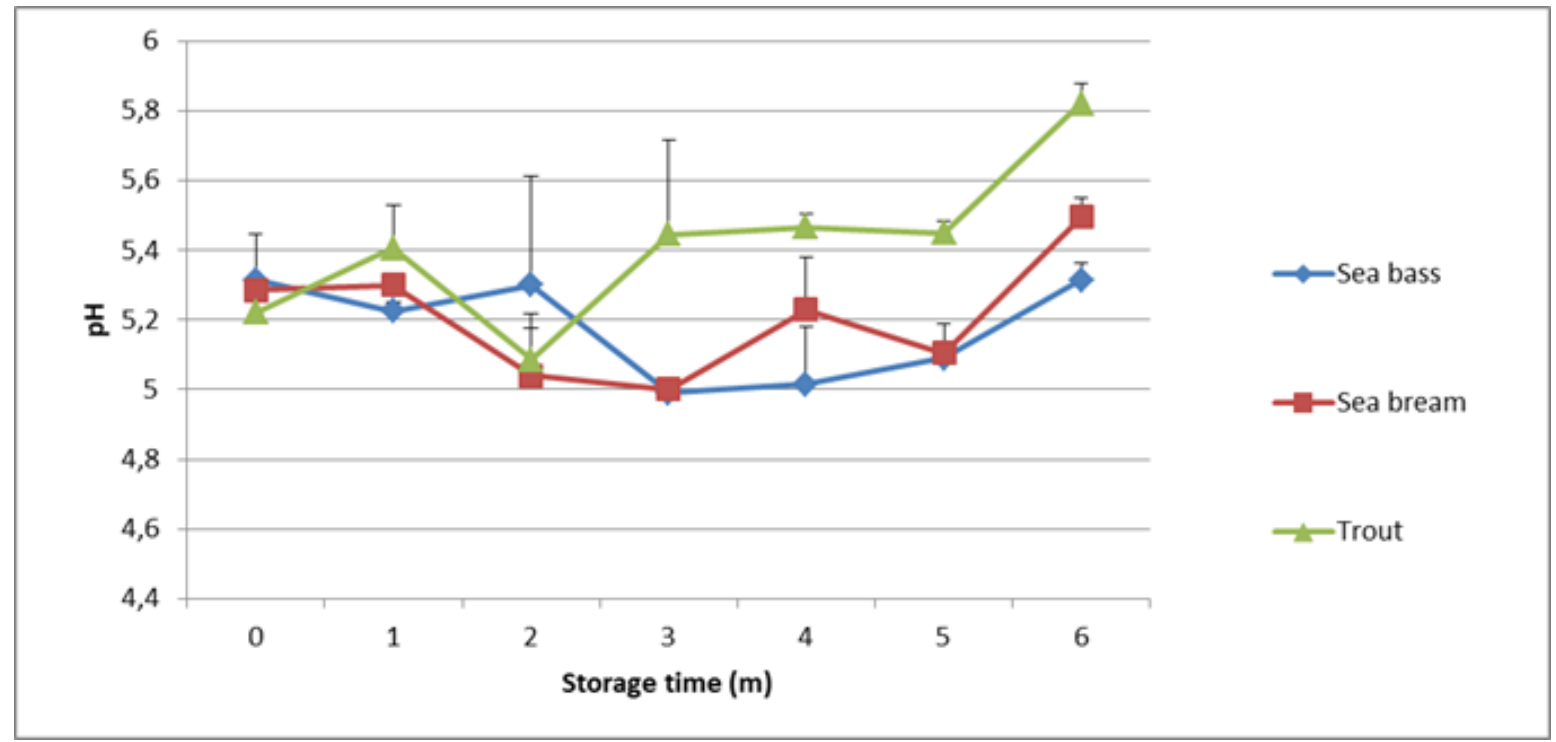

Figure 1. $\mathrm{pH}$ values changes of powdered soup samples during the storage time

TBA values of the soup samples were shown in Figure 2. It was statistically significant relationship between the storage time and the TBA values ( $p \leq 0.05)$. TBA values of the soup samples have been increased during the storage period and the highest increase has been found to occur in TS soup samples. It was found to be increased levels, such as $3.05 \mathrm{mg}$ MA $/ \mathrm{kg}$ in SBRS soup samples, 2.39 and $3.30 \mathrm{mg} \mathrm{MA} / \mathrm{kg}$ in the SBS and TS soup samples during the storage period. 


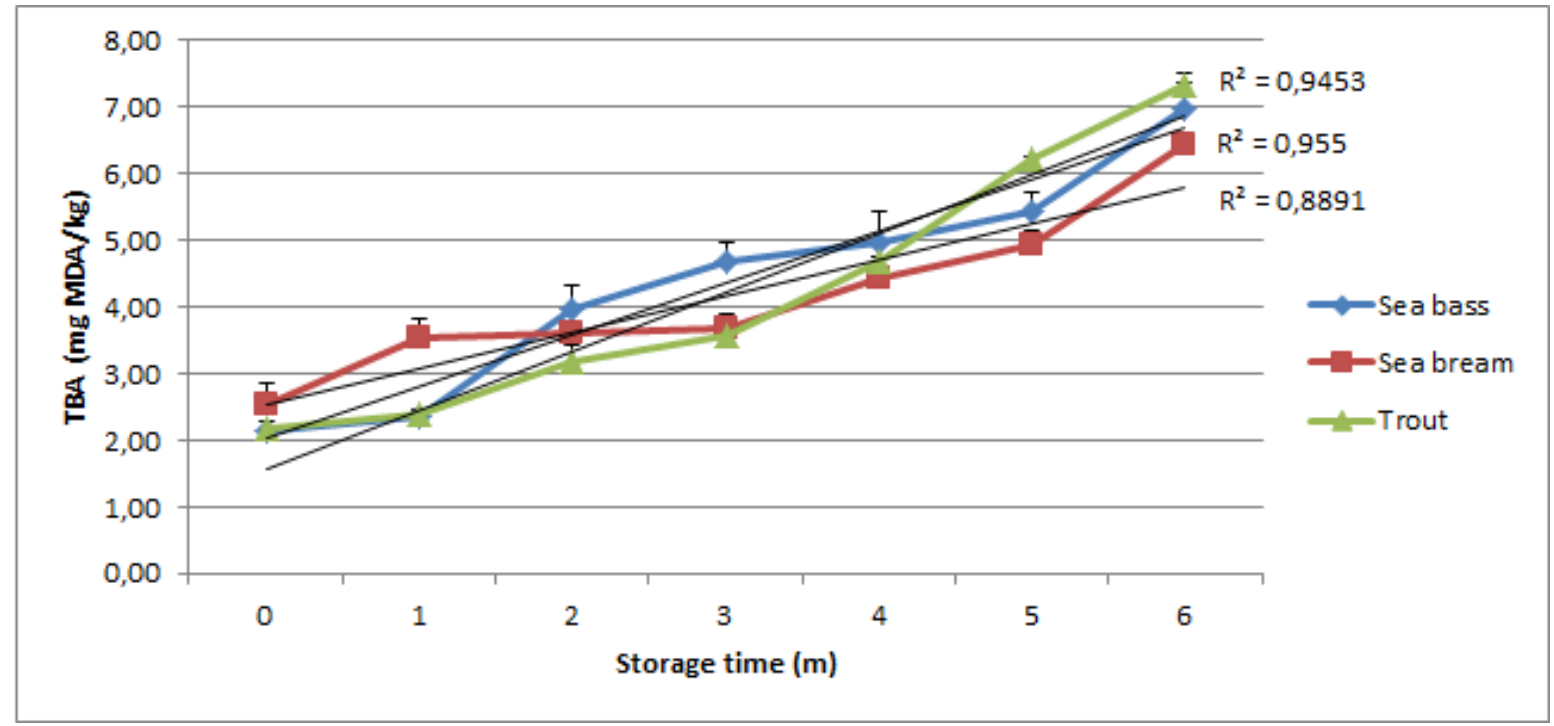

Figure 2. TBA values changes of powdered soup samples during the storage time

TVB-N values of the soup powder samples were shown in Figure 3. It was statistically significant relationship between the storage time and the TVB-N values $(p \leq 0.05)$. As shown in Figure 3, TVB-N values of fish soup samples were increased during the storage period in our study.

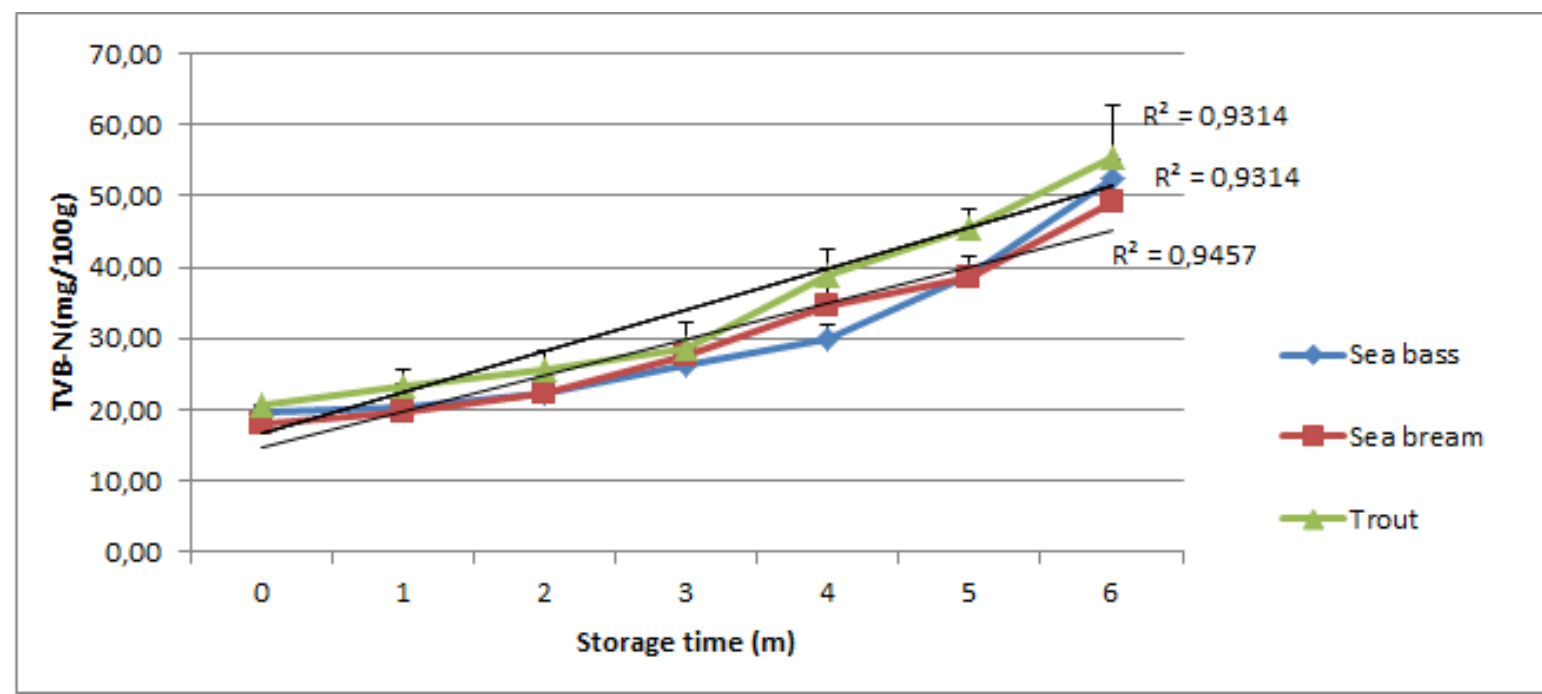

Figure 3. TVB-N values changes of powdered soup samples during the storage time

The results of fish soup samples microbiological analyses were given in Table 3 . When the values given in Table 3 were examined, it was determined that the total number of mesophilic aerobic bacteria (TMAB) increased throughout the storage period and reached the highest value in the last month of storage. There was a similar increase in total yeast and mold counts. The values of total coliform microorganisms were found to remain within the consumption limits (excluding the first month) of less than $2.00 \mathrm{log} \mathrm{CFU} / \mathrm{g}$ during storage. Staphylococcus spp. counts of the samples have shown an increase of about 1 logarithmic unit during storage. Salmonella spp. was not detected in all fish soup samples as expected. 
Table 3. The microbiological analysis results of powdered soup samples (log CFU/g)

\begin{tabular}{|c|c|c|c|c|c|c|c|c|}
\hline \multirow{2}{*}{$\begin{array}{c}\text { Microbiological } \\
\text { analyzes }\end{array}$} & \multirow{2}{*}{ Groups* } & \multicolumn{7}{|c|}{ Storage time $(\mathrm{m})$} \\
\hline & & 0 & 1 & 2 & 3 & 4 & 5 & 6 \\
\hline \multirow{3}{*}{$\begin{array}{c}\text { Total aerobic } \\
\text { mesophilic } \\
\text { bacteria }\end{array}$} & SBRS & $5.49^{\mathrm{aA}} \pm 0.10$ & $5.45^{\mathrm{aB}} \pm 0.12$ & $5.35^{\mathrm{aB}} \pm 0.38$ & $5.76^{\mathrm{aAB}} \pm 0.40$ & $5.44^{\mathrm{aB}} \pm 0.50$ & $5.80^{\mathrm{aAB}} \pm 0.13$ & $5.86^{\mathrm{aAB}} \pm 0.05$ \\
\hline & SBS & $5.44^{\mathrm{aA}} \pm 0.01$ & $5.17^{\mathrm{aA}} \pm 0.08$ & $4.80^{\mathrm{aA}} \pm 0.34$ & $5.29^{\mathrm{aA}} \pm 0.12$ & $5.06^{\mathrm{aA}} \pm 0.03$ & $5.58^{\mathrm{aA}} \pm 0.7$ & $5.65^{\mathrm{aA}} \pm 0.07$ \\
\hline & TS & $5.46^{\mathrm{CA}} \pm 0.04$ & $5.50^{\mathrm{cB}} \pm 0.03$ & $4.93^{\mathrm{aA}} \pm 0.04$ & $5.25^{\mathrm{bA}} \pm 0.03$ & $5.59 \mathrm{cB} \pm 0.05$ & $5.81 \mathrm{dAB} \pm 0.04$ & $6.61^{\mathrm{eB}} \pm 0.10$ \\
\hline \multirow{3}{*}{$\begin{array}{c}\text { Total yeast and } \\
\text { mold } \\
\end{array}$} & SBRS & $2.38^{\mathrm{aA}} \pm 0.53$ & $2.57^{\mathrm{aA}} \pm 0.50$ & $2.63^{\mathrm{aAB}} \pm 0.14$ & $3.19^{\mathrm{aB}} \pm 0.99$ & $2.72^{\mathrm{aA}} \pm 0.10$ & $2.47^{\mathrm{aA}} \pm 0.18$ & $3.31^{\mathrm{aAB}} \pm 0.19$ \\
\hline & SBS & $2.73^{\mathrm{aAB}} \pm 0.16$ & $2.64^{\mathrm{aA}} \pm 0.60$ & $2.52^{\mathrm{aA}} \pm 0.37$ & $2.77^{\mathrm{aA}} \pm 0.63$ & $3.50 \mathrm{aBC} \pm 0.25$ & $3.87^{\mathrm{aB}} \pm 0.62$ & $3.80^{\mathrm{aB}} \pm 0.61$ \\
\hline & TS & $2.95^{\mathrm{aAB}} \pm 0.08$ & $2.77^{\mathrm{aAB}} \pm 0.05$ & $2.47^{\mathrm{aA}} \pm 0.08$ & $2.80 \pm^{\mathrm{aA}} 0.08$ & $3.11^{\mathrm{aB}} \pm 0.01$ & $3.61^{\mathrm{aB}} \pm 0.15$ & $3.16^{\mathrm{aA}} \pm 0.06$ \\
\hline \multirow{3}{*}{ Total coliforms } & SBRS & $2.63^{\mathrm{bB}} \pm 0.21$ & $<2.00^{\mathrm{aA}}$ & $<2.00^{\mathrm{aA}}$ & $<2.00^{\mathrm{aA}}$ & $<2.00^{\mathrm{aA}}$ & $<2.00^{\mathrm{aA}}$ & $<2.00^{\mathrm{aA}}$ \\
\hline & SBS & $2.15^{\mathrm{bAB}} \pm 0.04$ & $<2.00^{\mathrm{aA}}$ & $<2.00^{\mathrm{aA}}$ & $<2.00^{\mathrm{aA}}$ & $<2.00^{\mathrm{aA}}$ & $<2.00^{\mathrm{aA}}$ & $<2.00^{\mathrm{aA}}$ \\
\hline & TS & $<2.00^{\mathrm{aA}}$ & $<2.00^{\mathrm{aA}}$ & $<2.00^{\mathrm{aA}}$ & $<2.00^{\mathrm{aA}}$ & $<2.00^{\mathrm{aA}}$ & $<2.00^{\mathrm{aA}}$ & $<2.00^{\mathrm{aA}}$ \\
\hline \multirow{3}{*}{$\begin{array}{c}\text { Staphylococcus } \\
\text { spp. }\end{array}$} & SBRS & $3.17^{\mathrm{aB}} \pm 0.30$ & $3.59 \mathrm{aB} \pm 0.07$ & $3.92^{\mathrm{aB}} \pm 0.44$ & $3.86^{\mathrm{aAB}} \pm 0.03$ & $3.51 \mathrm{aAB} \pm 0.17$ & $3.26^{\mathrm{aA}} \pm 0.17$ & $3.29 \mathrm{aAB} \pm 0.02$ \\
\hline & SBS & $3.70^{\mathrm{aBC}} \pm 0.48$ & $3.52^{\mathrm{aB}} \pm 0.57$ & $3.48^{\mathrm{aB}} \pm 0.28$ & $3.45^{\mathrm{aAB}} \pm 0.08$ & $3.28^{\mathrm{aA}} \pm 0.53$ & $3.16^{\mathrm{aA}} \pm 0.29$ & $3.13^{\mathrm{aA}} \pm 0.07$ \\
\hline & TS & $2.66^{\mathrm{aA}} \pm 0.06$ & $2.76 \mathrm{abA} \pm 0.03$ & $2.88 \mathrm{abA} \pm 0.03$ & $3.28^{\mathrm{cA}} \pm 0.28$ & $3.37^{\mathrm{CA}} \pm 0.09$ & $3.12^{\mathrm{bcA}} \pm 0.16$ & $3.75^{\mathrm{aB}} \pm 0.09$ \\
\hline \multirow{3}{*}{ Salmonella spp. } & SBRS & ND & ND & ND & ND & ND & ND & ND \\
\hline & SBS & ND & ND & ND & ND & ND & ND & ND \\
\hline & TS & ND & ND & ND & ND & ND & ND & ND \\
\hline
\end{tabular}

*SBS: Sea bass soup. SBRS:Sea bream soup; TS: Rainbow trout soup **Data expressed as mean \pm SD. a-e: Values in the same row sharing the same superscript letter are not significantly different $(p>0.05)$. A-B: Values in the same column sharing the same superscript letter are not significantly different $(p>0.05)$. ND: Not detected 


\section{Sensory properties of fish soup samples}

Sensory evaluation results of the fish soup samples such as color, odor, appearance, chewing properties, flavor and overall acceptability parameters were given in Table 4. It was determined that the sensory values of the samples were decreasing during the storage period.

\section{DISCUSSION}

In general, the nutritional composition of soups will vary depending on the ingredients used [25]. Similar to the results that were given in Table 2, Warang et al. [16] were determined moisture, protein, fat and carbohydrate content of fish powder soup (Protonibeadiacanthus) respectively as $7.8,21.12,7.5$, and $43.57 \%$. Moni and Taheri [26] reported that protein, fat, moisture and ash values of powdered soup made from carp respectively $17.7 ; 4 ; 7.7$ and $1.3 \%$, similar to our study. Rahman et al. [26], another similar study, stated that $9.5 \%$ protein, $1.47 \%$ fat, $9.4 \%$ moisture, $14 \%$ ash and $65.7 \%$ carbohydrate levels in powder soup containing $10 \%$ dried carp meat. Islam et al. [3] determined that moisture, ash, fat, protein and carbohydrate content of the soup mixture containing silver carp fish powder as $9.4 \%, 15 \% ; 1.39 \% ; 9.4 \%$ and $64.71 \%$ respectively. In another study, it was found that ash, protein, fat, fiber and carbohydrate values of the type of powder of the soup produced from Sardinella longiceps as $10.61 \%, 3.18 \% ; 7.12 \% ; 4.64$ and $66.5 \%$ respectively [13]. Martínez-Tomé et al. [7], in another similar study, reported that the value of moisture, fat, protein, ash and carbohydrates $1.5 \% ; 0.9 \% ; 4.2 \% ; 67.2 \%$ and $25.7 \%$ at the beginning of storage of fish soups. Researchers stated that there was no significant change during the storage period of 12 months. It was determined that the moisture content of fish soups was low in other studies similar to our study results. Moisture plays an important role in food quality. When the moisture content exceeds $14 \%$, the storage quality of the powdered foods is affected adversely, because of mold growth, insect infestation, and clustering. In addition, almost all reactions that cause food breakdown are delayed or stopped completely by providing moisture control [27]. The nutrient composition of fish soups varies depending on the fish species and the other components used in soup formulation. It was determined that the nutritional value could be increased depending on the added components. Today, many contemporary foods on the market are rich in carbohydrates and fats, however, are inadequate in terms of protein and calcium. Consumption of such foods for a certain period may cause overweight, obesity, hypertension, atherosclerosis, diabetes, osteopenia, osteoporosis [5]. As seen in our study, it is clear that the fish soup, which is rich in protein and mineral content, will be a good alternative to avoid such health problems.

The $\mathrm{pH}$, TBA and TVN-B values changes of the samples are shown in Figures 1, 2 and 3. Similarly to the results of this study, Kılınç [28] was determined that $\mathrm{pH}$ value was raised from 6.22 at zero-day to 6.42 at 6 th day. It was stated that $\mathrm{pH}$ value of fish species, which varies depending on the catching and processing method. However, the $\mathrm{pH}$ value cannot be used as an indicator alone for quality; it should be used to combine with other quality parameters. Mol [29] reported that the $\mathrm{pH}$ value of fish soup was 5.97 after the production and reduction were seen at the end of storage, but was not determined a relationship between the deterioration of the soup sample and the $\mathrm{pH}$ value. 
Table 4. The results of the sensory properties of powdered fish soup samples

\begin{tabular}{|c|c|c|c|c|c|c|c|c|}
\hline \multirow{2}{*}{$\begin{array}{c}\text { Sensory } \\
\text { properties }\end{array}$} & \multirow{2}{*}{ Groups* } & \multicolumn{7}{|c|}{ Storage time $(\mathrm{m})$} \\
\hline & & 0 & 1 & 2 & 3 & 4 & 5 & 6 \\
\hline \multirow{3}{*}{ Color } & SBS & $8.4^{\mathrm{CB}} \pm 0.84$ & $7.8^{\mathrm{CAB}} \pm 1.03$ & $7.9^{\mathrm{cC}} \pm 0.88$ & $7.5^{\mathrm{bcB}} \pm 0.53$ & $6.9^{\mathrm{abc} A \mathrm{~B}} \pm 1.10$ & $6.3^{\mathrm{abB}} \pm 1.57$ & $6.0^{\mathrm{aB}} \pm 2.00$ \\
\hline & SBRS & $8.1^{\mathrm{CAB}} \pm 0.74$ & $7.6^{\mathrm{bcA}} \pm 1.08$ & $7.4^{\mathrm{abcB}} \pm 0.70$ & $6.9 \mathrm{abcA} \pm 0.88$ & $6.5^{\mathrm{abcA}} \pm 1.08$ & $6.3^{\mathrm{abB}} \pm 1.34$ & $5.8^{\mathrm{aAB}} \pm 1.40$ \\
\hline & TS & $7.7^{\mathrm{cA}} \pm 1.19$ & $7.5^{\mathrm{cA}} \pm 1.42$ & $6.9^{\mathrm{bcA}} \pm 1.27$ & $7.2^{\mathrm{bcAB}} \pm 0.67$ & $6.5^{\mathrm{abcA}} \pm 1.42$ & $5.9^{\mathrm{abA}} \pm 1.09$ & $5.4^{\mathrm{aA}} \pm 1.33$ \\
\hline \multirow{3}{*}{ Odor } & SBS & $7.8^{\mathrm{dA}} \pm 0.79$ & $6.7^{\mathrm{bcdA}} \pm 1.49$ & $7.2^{\mathrm{cdB}} \pm 1.67$ & $6.3^{\mathrm{abcdA}} \pm 1.16$ & $5.7 \mathrm{abcA} \pm 1.89$ & $5.0 \mathrm{abA} \pm 1.70$ & $4.7^{\mathrm{aA}} \pm 1.06$ \\
\hline & SBRS & $8.0^{\mathrm{CAB}} \pm 1.05$ & $7.2^{\mathrm{bcB}} \pm 1.23$ & $7.1^{\mathrm{bcB}} \pm 1.20$ & $6.5^{\mathrm{abA}} \pm 1.72$ & $6.2^{\mathrm{abB}} \pm 1.22$ & $5.5^{\mathrm{aB}} \pm 1.27$ & $5.9^{\mathrm{abB}} \pm 1.37$ \\
\hline & TS & $8.4^{\mathrm{CB}} \pm 0.84$ & $7.1^{\mathrm{bB}} \pm 1.29$ & $6.2^{\mathrm{abA}} \pm 1.23$ & $6.4^{\mathrm{abA}} \pm 1.43$ & $6.0 \mathrm{abAB} \pm 1.41$ & $5.3^{\mathrm{abAB}} \pm 1.16$ & $4.9 \mathrm{aA} \pm 0.99$ \\
\hline \multirow{3}{*}{ Appearance } & SBS & $8.3^{\mathrm{dAB}} \pm 0.95$ & $8.1^{\mathrm{dAB}} \pm 0.99$ & $7.7^{\mathrm{cdB}} \pm 0.95$ & $6.7^{\mathrm{bcA}} \pm 1.06$ & $6.2^{\mathrm{bA}} \pm 1.87$ & $5.0^{\mathrm{aA}} \pm 1.49$ & $4.2^{\mathrm{aA}} \pm 1.14$ \\
\hline & SBRS & $8.1^{\mathrm{aA}} \pm 0.99$ & $7.7^{\mathrm{aA}} \pm 0.95$ & $6.7^{\mathrm{aA}} \pm 1.16$ & $7.8^{\mathrm{aB}} \pm 1.23$ & $7.3^{\mathrm{aB}} \pm 1.34$ & $7.2 \mathrm{aC} \pm 1.14$ & $7.0^{\mathrm{aB}} \pm 0.67$ \\
\hline & TS & $8.1^{\mathrm{bA}} \pm 0.74$ & $7.8^{\mathrm{bA}} \pm 0.92$ & $7.2^{\mathrm{bAB}} \pm 1.03$ & $7.4^{\mathrm{bAB}} \pm 1.26$ & $7.3^{\mathrm{bB}} \pm 1.70$ & $6.6^{\mathrm{bB}} \pm 2.02$ & $4.9^{\mathrm{aA}} \pm 1.19$ \\
\hline \multirow{3}{*}{$\begin{array}{l}\text { Chewing } \\
\text { feature }\end{array}$} & SBS & $7.6 \mathrm{~B}^{\mathrm{c}} \pm 1.05$ & $7.3^{\mathrm{cB}} \pm 1.34$ & $7.0^{\mathrm{cB}} \pm 0.94$ & $6.6^{\mathrm{bcB}} \pm 1.51$ & $6.1^{\mathrm{abcB}} \pm 1.91$ & $5.2^{\mathrm{abB}} \pm 1.03$ & $5.0^{\mathrm{aB}} \pm 0.67$ \\
\hline & SBRS & $6.2^{\mathrm{cA}} \pm 1.23$ & $6.8^{\mathrm{cA}} \pm 1.40$ & $5.6^{\mathrm{bcA}} \pm 1.35$ & $5.3^{\mathrm{abcA}} \pm 1.57$ & $4.2^{\mathrm{abA}} \pm 1.14$ & $3.9^{\mathrm{aA}} \pm 0.99$ & $4.3^{\mathrm{abA}} \pm 0.95$ \\
\hline & TS & $7.7^{\mathrm{cdB}} \pm 1.06$ & $7.9^{\mathrm{dB}} \pm 0.99$ & $7.4^{\mathrm{cdB}} \pm 1.26$ & $6.8^{\mathrm{bcdB}} \pm 1.31$ & $6.1^{\mathrm{abcB}} \pm 1.45$ & $5.5^{\mathrm{abB}} \pm 1.58$ & $5.0^{\mathrm{aB}} \pm 1.70$ \\
\hline \multirow{3}{*}{ Flavor } & SBS & $8.1^{\mathrm{dA}} \pm 0.88$ & $8.0^{\mathrm{dA}} \pm 0.67$ & $7.5^{\mathrm{Cd} A B} \pm 1.43$ & $7.1^{\mathrm{cdB}} \pm 1.10$ & $6.2^{\mathrm{bcB}} \pm 1.48$ & $5.7^{\mathrm{abAB}} \pm 1.06$ & $4.8^{\mathrm{aB}} \pm 1.69$ \\
\hline & SBRS & $8.4^{\mathrm{CAB}} \pm 0.52$ & $7.9^{\mathrm{cA}} \pm 1.10$ & $7.5^{\mathrm{CAB}} \pm 0.71$ & $6.2^{\mathrm{bA}} \pm 1.62$ & $5.9^{\mathrm{bAB}} \pm 1.29$ & $5.7^{\mathrm{bAB}} \pm 1.06$ & $4.3^{\mathrm{a} A \mathrm{~B}} \pm 1.64$ \\
\hline & TS & $8.7^{\mathrm{CB}} \pm 0.48$ & $8.0^{\mathrm{bcA}} \pm 0.94$ & $7.0^{\mathrm{bA}} \pm 1.94$ & $6.8^{\mathrm{bAB}} \pm 0.92$ & 5. $1^{\mathrm{aA}} \pm 1.91$ & $5.3^{\mathrm{aA}} \pm 1.70$ & $4.1^{\mathrm{aA}} \pm 1.79$ \\
\hline \multirow{3}{*}{$\begin{array}{c}\text { Overall } \\
\text { acceptability }\end{array}$} & SBS & $7.6^{\mathrm{dA}} \pm 0.96$ & $7.0^{\mathrm{cdA}} \pm 0.94$ & $6.8^{\mathrm{cdA}} \pm 1.75$ & $5.8^{\mathrm{bcA}} \pm 1.40$ & $5.1^{\mathrm{abA}} \pm 1.37$ & $4.8^{\mathrm{abA}} \pm 1.14$ & $3.8^{\mathrm{aA}} \pm 1.23$ \\
\hline & SBRS & $7.8^{\mathrm{cAB}} \pm 0.79$ & $7.9^{\mathrm{cBC}} \pm 1.10$ & $6.9^{\mathrm{bcA}} \pm 0.99$ & $6.0^{\mathrm{abc} A \mathrm{~B}} \pm 1.41$ & $5.7^{\mathrm{abAB}} \pm 1.57$ & $5.9^{\mathrm{abcB}} \pm 5.90$ & $4.7^{\mathrm{aB}} \pm 1.42$ \\
\hline & TS & $8.2^{\mathrm{dB}} \pm 0.63$ & $7.5^{\mathrm{cdB}} \pm 1.27$ & $7.7^{\mathrm{cdB}} \pm 1.16$ & $6.5^{\mathrm{bcB}} \pm 1.35$ & $6.0^{\mathrm{bB}} \pm 1.41$ & $5.2^{\mathrm{abAB}} \pm 1.62$ & $4.2^{\mathrm{aAB}} \pm 1.40$ \\
\hline
\end{tabular}

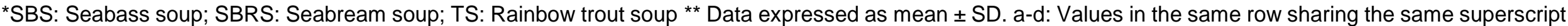
letter are not significantly different $(p>0.05)$. A-C: Values in the same column sharing the same superscript letter are not significantly different $(p>0.05)$ 
Oxidation of fish oil comes from the leading causes of rancidity or spoilage in fishes. Fats in the composition of meat and meat products are exposed to oxidative reactions during storage. The most widely used method of determining the lipid oxidation level of meat and meat products is TBA assay based on the determined amount of the malondialdehyde (MA). MA by resulting of the lipid oxidation adsorbing the product is an important criterion for determining the oxidation level. $1 \mathrm{mg} \mathrm{MA} / \mathrm{kg}$ of TBA value is "very good", $1-3 \mathrm{mg}$ of ME/kg of "good", 3-5 mg MA/kg "medium", 5-8 mg MA/kg "low" and $8 \mathrm{mg} \mathrm{MA} / \mathrm{kg}$ are considered to be corrupt [30]. In our study, TBA levels of fish soup samples were increased during the storage and the highest increase was found to occur in rainbow trout soup samples. TBA value, which was about $2 \mathrm{mg} \mathrm{MA} / \mathrm{kg}$ at the beginning of storage, was reached to $5 \mathrm{mg} \mathrm{MA} /$ $\mathrm{kg}$ at $6^{\text {th }}$ months and it remained at the level of acceptability (Figure 2). Tolasa et al. [31] reported that TBA values of fish soups were determined as being lower than $1 \mathrm{mg} \mathrm{MA} / \mathrm{kg}$ at the beginning of the storage at $3^{\circ} \mathrm{C}$ and significantly increased after 8 months of the storage period $(0.83 \pm 0.09)$. While TVB-N values of TS, SBS and SBRS soup samples were respectively 20.72; 18.12 and $19.52 \mathrm{mg} / 100 \mathrm{~g}$ initially, TVB-N values exceeded the consumption limit which is $35 \mathrm{mg} \mathrm{N} / 100 \mathrm{~g}$ in 4th months of storage period for the rainbow trout soup samples and in 5th months of storage period for sea bass and sea bream soup samples. Moni and Taheri [26] reported that TVB-N value of carp soup reached from 28 up to $39.8 \mathrm{mg} / 100 \mathrm{~g}$ from the start of the storage to 60 days. The TVB-N value which determined as $11.73 \mathrm{mg} \mathrm{N} / 100 \mathrm{~g}$ at the beginning of the storage period of pasteurized soup samples prepared smoked fish waste and cold stored significantly increased over the 4th months of storage period in a study carried out by Tolasa et al. [31]. TVB-N value has reached the maximum limit of $23.78 \mathrm{mg} \mathrm{N} / 100$ level in 4th months and this level were found close to the European Commission (EC) limit for fresh fish. No significant change is over 4th months and the TVB-N value was reached at the end of the 8th month. The shelf life was determined as 8 months in this study.

In general, when examining the microbiological properties determined for all fish soup samples, it can be said that the values found are within the consumption limits during storage and the microbiological qualities of the samples are acceptable. Moni and Taheri [25] reported that the number of TMAB of carp soup was increased to $1.5 \times 10^{4} \mathrm{CFU} / \mathrm{g}$ storage period of 60-day. Kılınç [28] reported that while the number of TMAB identified in raw anchovy was $3.65 \mathrm{log} \mathrm{CFU} / \mathrm{g}$, total mesophilic, psychrotrophic and total yeast and mold count have decreased significantly after the soups production stage. The number of TMAB was $2.23 \mathrm{log}$ CFU/g in soups at the beginning of the storage; it showed an increase during storage and has reached critical limits as $6.1 \mathrm{log}$ CFU/g at $6^{\text {th }}$ month. Total coliform, yeast and mold, S. aureus, E. coli and Salmonella spp. not detected during the storage time. In another similar study, the powdered fish soup prepared using three different fishes, starch ratio $(1: 1,2: 1 ; 3: 1)$ was vacuum packed, and the microbial and biochemical quality of samples was determined in the storage period. The total bacterial count of all samples during the 14-day storage period was determined that between 216 and $289 \mathrm{CFU} / \mathrm{g}$, coliform and Salmonella was not detected. It was reported that the packaging type did not affect the total bacterial count at the end of the study [5]. Udari et al. [13] reported that the number of bacteria in fish soup produced using Sardinella longiceps increased depending on the storage period and total bacterial count reached $4.1 \times 10^{3} \mathrm{CFU} / \mathrm{g}$ and total yeast-mold count reached $1.7 \times 10^{2} \mathrm{CFU} / \mathrm{g}$. In another study, which examined the same fish species, the total bacteria and total yeast mold count of the soup containing $9.7 \%$ fish powder and $3.0 \%$ fish oil were $4 \times 10^{2} \mathrm{CFU} / \mathrm{g}$ and $1 \times 10^{2} \mathrm{CFU} / \mathrm{g}$, respectively [32].

Sensory properties of the samples were determined and shown in Table 4. When the samples are compared in terms of color values, the results are seen to vary between $5.41 \pm 1.33-8.4 \pm 0.84$. There is a significant relationship between color values and storage time of the samples. A reduction of the color values of samples was appear at the end of the storage period $(p \leq 0.05)$. When the fish soup groups were compared among themselves, the difference between SBS groups and TS group samples was found statistically significant. Accordingly, the highest color value of the SBS group samples have in the first month of 
storage, while the lowest color value of the TS group samples have in the $6^{\text {th }}$ month of storage. Islam et al. [3], in a similar fish soup study, was used a 1-5-point color score scale and they reported that the color values of the samples ranged between $4.20 \pm 0.41$ $4.40 \pm 0.50$. Bamidele et al. [33], in a similar study, were used a 9-point color score scale and they stated that the color values of the samples ranged as 3.60-5.26. It is thought that this difference is caused by the different fish species and ingredient substances used in soup samples production. According to the results of our study, it can be said that the color sensory properties of the samples were acceptable during a storage period of 6 months. When the odor values of the samples were evaluated (Table 4), it was determined that the odor values of all the samples decreased during the storage period and reached the lowest value in the last month of storage $(p \leq 0.05)$. The samples are generally of statistical significance differences when compared to each other even though they have similar values in the 3th month of storage ( $p \leq 0.05)$. According to the results of our study, it was determined that while TS group samples has the highest odor score values at the beginning of storage $(8.4 \pm 0.84)$, SBS group has the lowest odor score samples at the 6th month of storage to the values $(4.7 \pm 1.06)$. The odor values obtained from our study were found to be quite high compared to the odor results (4.50 - 5.45) of a similar study by Bamidele et al. [33]. When the appearance values of the soup samples were examined (Table 4), it was determined that the appearance values of all the samples decreased during the storage period $(p \leq 0.05)$. In general, SBS group samples have the highest and lowest appearance values in the first and $6^{\text {th }}$ months of storage when the samples are compared among each other. In literature, it is seen that the value of appearance in the samples of fish soups is not a value as a sensory properties examined by other publications. In general, when the appearance values of all samples were examined, it was determined that the values were within acceptable limits during the first 4 months of storage. When were examined the chewing feature values of the soup samples (Table 4) it was seen that all samples have a regular reduction in the chewing feature values during the storage period. It was determined that the chewing feature values of SBRS group samples had statistically significant differences compared to the other group samples $(p \leq 0.05)$. According to the results, while TS group samples have the highest chewing feature values $(7.9 \pm 0.09)$, the lowest chewing feature values was observed to have SBRS group samples $(3.9 \pm 0.99)$. Generally, in literature, it is seen that the textural properties of fish soups were examined. The chewing features show similar properties with the textural features. Bamidele et al. [33] reported that the textural values of the samples ranged as 4.30-5.65. The results of our study showed higher acceptableness values according to chewing feature results than this study. This situation is thought to be caused by the fish species and other ingredients used in preparing fish soup samples. When the flavor values of the samples are examined, there is a statistically significant difference between the first month and the last month of storage period in all groups ( $\leq \leq 0.05)$. It was determined that all samples had approximately flavor values during the same months of storage. It was found that the TS group samples have the highest and lowest flavor values in the first $(8.7 \pm 0.48)$ and last months $(4.1 \pm 1.79)$ of storage. In a similar study by Bamidele et al. [33], it was observed that the flavor values of fish soup samples ranged between 4.505.45 . When the samples are evaluated in terms of overall acceptability values, it is seen that there was a regular decrease in the values during the storage period. It was determined that this reduction was statistically significant for all fish soup samples $(p \leq 0.05)$. It was found that TS group samples have the highest overall acceptability values at the beginning of storage, while SBS group samples have the lowest values at the end of storage. In a similar study by Bamidele et al. [33] stated that the overall acceptability values of fish soup samples ranged as 4.60-6.10.

Consequently, it was determined that the SBS soup samples received the highest score in terms of color. From the point of view of odor and appearance, it was seen that SBRS is the most favorite sample. SBS and TS soup samples were the most favorite fish soup samples in terms of chewable properties. While the most popular soup samples in terms of flavor were SBS, the least appreciated samples during storage were TS soup samples. 
Finally, in terms of overall acceptability, the most popular samples were TS soup samples, which are followed by SBRS and SBS samples respectively.

Fats in the composition of meat and meat products are exposed to oxidative reactions during storage. Therefore, loss of flavor and rancidity are concerned due to oxidation occurred during storing of seafood product which contains highly unsaturated oil particularly $[8,10,13]$. It was found to be the oxidation level of soups applied boiled process lower, hence that it was a higher shelf life in our study. In addition, it was demonstrated that the fat content increases shelf life.

\section{CONCLUSION}

The food of animal origin is great in human nutrition. In particular, the adequate nutrition of children and young people in terms of animal nutrition is extremely important in terms of mental development as well as physical growth. The sea foods, which is superior in terms of properties such as protein, energy, mineral substances, vitamins and digestibility, is a resource that can contribute to the lack of protein deficiency in humans and to the change of nutritional habits positively. While most of the seafood products are consumed as fresh and chilled, the demand for ready-to-eat food has increased considerably in recent years. At this point, delicious, practical and high quality varieties of ready-to- package soup, concentrates and powder blends are becoming an important option with new formulations. Healthy, nutritious, high-quality delicacies can be brought to the kitchen with dried and powdered soups.

As a conclusion of this study, a food production has been realized that has high nutritional value, has a long shelf life and ease of handling, a short time can be ready for consumption. It is thought that the production of soup powder as well as to provide a significant advantage to increase the product range and evaluation of seafood products and thus expected to contribute to the national economy and the outputs of this project will contribute to the literature data and work in this area will lead to the investigators.

Funding: This study was supported by unit of scientific research projects of İzmir Katip Çelebi University with Project No: 2013-3-FMBP-29, BAP.

Conflicts of Interest: The authors declare no conflict of interest.

\section{REFERENCES}

1. Bülbül HS. Çocuk beslenmesinde demirin yeri ve önemi. Sürekli Tıp Eğt Derg. 2004 Dec;13(12): 446-450.

2. Kurtkaya G. Marine edilmiş levrek (Dicentrarchus labrax L., 1758) ve karabalıkta (Clarias gariepinus Burchell, 1822) depolama süresince duyusal, kimyasal ve mikrobiyolojik değişimler. [PhD thesis]. Mersin: Mersin University, Graduate School of Natural and Applied Sciences; 2009. $165 \mathrm{p}$.

3. Islam M, Sarker MNI, Islam MS, et al. Development and quality analysis of protein enriched Instant soup mix. Food and Nutr Sci. 2018 Jun;9(06):663.

4. Farzana T, Mohajan S, Saha T, Hossain MN, Haque MZ. Formulation and nutritional evaluation of a healthy vegetable soup powder supplemented with soy flour, mushroom, and moringa leaf. Food Sci \& Nutr. 2017 Jul;5(4):911-920.

5. Sarah Priscilla S, Vigasini N. Microbial and biochemical quality of fish soup powder prepared using white bait (Stolephorous spp.) with bones. Int J of Home Sci. 2017 Jan;3(1):316-318.

6. Chiang PD, Yen CT, Mau JL. Non-volatile taste components of various broth cubes. Food Chem. 2007 Feb;101(3):932-937.

7. Martínez-Tomé M, Murcia MA, Mariscal M, Lorenzo ML, Gómez-Murcia V, Bibiloni M, JiménezMonreal AM. Evaluation of antioxidant activity and nutritional composition of flavoured 
dehydrated soups packaged in different formats. Reducing the sodium content. J of Food Sci and Tech. 2015 Dec;52(12):7850-7860.

8. Shashidhar K, Ravishankar CN, Gopal TS, Joseph J. Standardization of process parameters for ready-to-drink shrimp soup in reportable pouches. Fishery Techn. 2014; 51:43-46.

9. Kaur S, Das M. Nutritional and functional characterization of barley flax seed based functional dry soup mix. J of Food Sci and Techn. 2015 Sep;52(9):5510-5521.

10. Radha C, Ogunsina BS, Hebina Babu KT. Some quality and micro-structural characteristics of soup enriched with debittered moringa oleifera seeds flour. American $\mathrm{J}$ of Food Sci and Techn. 2015 Nov;3(5):145-149.

11. Chellaram C, Anand TP, Praveen MM, Murugaboopathi G, Sivakumar R, Kumar BA, Krithika S. Self-life studies on an underutilized sea food from southeast coast of India. APCBEE Procedia. 2014; 8:114-118.

12. Adegoke $\mathrm{BH}$, Adedayo $\mathrm{AE}$, Temilola $\mathrm{D}$. Proximate, phytochemical and sensory quality of instant pepper soup mix. J of Culinary Sci \& Techn. 2016 Dec;14(1):59-74.

13. Udari AHGS, Wickramasinghe I, Attygalle MVE. Development of an omega 3 enriched instant soup powder from Sardinella longiceps. Int J of Engineering Sci Res Techn. 2015 Aug;644-652.

14. Ulusoy Ş, Doğruyol H, Alakavuk DÜ, Tosun ŞY. Monosodyumglutamatın balık çorbası ve balık köftesinin duyusal özellikleri üzerine etkisi. Gıda. 2017 Mar;42(4):339-347.

15. Turan H, Kaya Y, Sönmez G. Balık Etinin Besin Değeri ve İnsan Sağığındaki Yeri, E.U. J of Fisheries \& Aquatic Sci. 2006; 23(1/3):505-508.

16. Warang MD, Mulye VB, Sapkale PH, Bondre RD, Mohita AS. Fish soup powder production from Protonibeadiacanthus. The Asian J of Ani Sci. 2008; 381:19-23.

17. FAO. Fishery and aquaculture statistics. 2014.

18. Karapınar M, Gönül ŞE. Microbiological quality of dry soups obtained retail markets. Ege Üni Müh Fak Derg. 1989; 7(2):47-54.

19. Çoksaygııı N, Başoğlu F. Bursa piyasasında satılan hazır toz çorbaların mikrobiyolojik ve bazı kimyasal özellikleri. Uludağ Üni Ziraat Fak Derg. 2011 Mar;25(1):87-95.

20. AOAC. Official Methods of Analysis. Association of Official Analytical Chemists. Washington, DC., USA. 2000.

21. Tarladgis BG, Watts BM, Yonathan M. Distillation method for the determination of malonaldehyde in rancid foods. J of American Oil Chem Soc. 1960 Jan;37(1):44-48.

22. Goulas $A E$, Kontominas MG. Effect of salting and smoking-method on the keeping quality of chub mackerel (Scomber japonicus): biochemical and sensory attributes. Food Chem. 2005 Dec; 93:511-520.

23. FDA. Bacteriolological Analytical Manual. Food and Drug Administration 16 th Edition. AOAC Int. Gaithersburg MD; 1998.

24. Abdel-Haleem AMH, Omran AA. Preparation of dried vegetarian soup supplemented with some legumes. Food and Nutr Sci. 2014 Dec; 5:2274-2285.

25. Moni S, Taheri SM. Soup powder production from common carp (Cyprinus Carpio) and its shelf life. $\mathrm{J}$ of Fisher. 2009; 62(1):50-55.

26. Rahman MA, Sarfullah M, Islam MN. Fish powder in instant fish soup mix. J of Bangladesh Agricult Uni. 2012 Oct;10(1):145-148. 
27. Aziah AN, Komathi CA. Physicochemical and functional properties of peeled and unpeeled pumpkin in flour. J of Food Sci. 2009 Sep;74(7):328-333.

28. Kılınç B. Preparation of liquid anchovy (Engraulis encrasicholus) soup and microbiological and sensory changes during refrigerated storage. J of Muscle Foods. 2010 Jun;21:451-458.

29. Mol S. Preparation and the shelf-life assessment of ready-to-eat fish soup. European Food Res Techn. 2005 Oct;220:305-308.

30. Varlık C, Ugur M, Gökoglu N, Gün H. Su ürünlerinde kalite kontrol ilke ve yöntemleri. Gıda Teknolojisi Dergisi; 1993. 174 p.

31. Tolasa Ş, Çaklı Ş, Kışla D, Dinçer T. Quality and shelf life assessment of pasteurized trout soup during refrigerated storage. J of Aquatic Food Pro Techn, 2012 Aug;21:321-329.

32. Udari AHGS, Wickramasinghe I, Attygalle MVE. Effects of cooking on omega 3 content of Sardinella longiceps emphasizing an innovative method to elevate omega 3 intake. Int $\mathrm{J}$ of Innovative Res Techn. 2015 Aug;2(3):68-75.

33. Bamidele OP, Ojedokun OS, Fasogbon BM. Physico-chemical properties of instant ogbono (Irvingia gabonensis ) mix powder, Food Sci \& Nutr. 2015 Mar;3(4):313-318.

(C) 2018 by the authors. Submitted for possible open access publication under the terms and conditions of the Creative Commons Attribution (CC BY NC) license (https://creativecommons.org/licenses/by-nc/4.0/). 